\title{
De dominee en 'de tweede apostel Paulus'
}

Citation for published version (APA):

van den Berg, J. T. J. (2012). De dominee en 'de tweede apostel Paulus'. Maastricht University. https://doi.org/10.26481/spe.20120927jb

Document status and date:

Published: 27/09/2012

DOI:

10.26481/spe.20120927jb

Document Version:

Publisher's PDF, also known as Version of record

\section{Please check the document version of this publication:}

- A submitted manuscript is the version of the article upon submission and before peer-review. There can be important differences between the submitted version and the official published version of record.

People interested in the research are advised to contact the author for the final version of the publication, or visit the DOI to the publisher's website.

- The final author version and the galley proof are versions of the publication after peer review.

- The final published version features the final layout of the paper including the volume, issue and page numbers.

Link to publication

\footnotetext{
General rights rights.

- You may freely distribute the URL identifying the publication in the public portal. please follow below link for the End User Agreement:

www.umlib.nl/taverne-license

Take down policy

If you believe that this document breaches copyright please contact us at:

repository@maastrichtuniversity.nl

providing details and we will investigate your claim.
}

Copyright and moral rights for the publications made accessible in the public portal are retained by the authors and/or other copyright owners and it is a condition of accessing publications that users recognise and abide by the legal requirements associated with these

- Users may download and print one copy of any publication from the public portal for the purpose of private study or research.

- You may not further distribute the material or use it for any profit-making activity or commercial gain

If the publication is distributed under the terms of Article $25 \mathrm{fa}$ of the Dutch Copyright Act, indicated by the "Taverne" license above, 
Prof. dr. J .Th.J . van den Berg

Faculteit der Rechtsgeleerdheid

\section{De dominee en 'de tweede apostel Paulus'}


Prof. dr. J.Th.J. van den Berg

\section{De dominee en}

\section{'de tweede apostel Paulus'}

Afscheidscollege Maastricht University

27 september 2012 


\section{Mijnheer de Rector Magnificus; Dames en Heren,}

[1] Ter inleiding: vergeten geschiedenis.

Een jaar of zes geleden zaten wij met het voorlopige bestuur van wat later het Montesquieu Instituut zou worden bijeen om te spreken over het karakter en de taken van het instituut. Dus kwam ook de vraag op hoe het zou moeten heten. Ik deed daarop het voorstel het te noemen naar Pieter Paulus, de eerste voorzitter van de Nationale Vergadering van 1796, de voorgangster van onze Tweede Kamer. Het gezelschap van geleerde historici, juristen en politicologen keek mij collectief aan met glazige blik: Pieter Wie?! Niemand wist over wie ik het had. Dat, terwijl ik toch niet werd omgeven door collegae die bij de geschiedenisles vroeger bij voorkeur waren gaan spijbelen. Op voorstel van prof. Carla van Baalen is de naam Montesquieu Instituut gekozen. Ook een heel mooie naam, natuurlijk.

Te vrezen valt dat de naam van Pieter Paulus de meesten van U hier vanmiddag eveneens onbekend is. Wat minder zegt over $U$ dan over de onuitroeibare neiging, ook onder historici, om een van de meest vormende perioden in de vaderlandse politieke geschiedenis onder de mat te vegen en te doen alsof de geschiedenis van de moderne natiestaat Nederland pas in 1813-1814 zou zijn begonnen; alsof onze geschiedenis het dus niet kan stellen zonder Oranje. Als alleen notoire orangisten dat nu zouden willen doen geloven; maar nee, ook wetenschappers die noch orangistisch noch oud-liberaal zijn, werken ijverig mee aan het verdonkeremanen van de 'Bataafs-Franse periode' in onze constitutionele geschiedenis ${ }^{1}$. Voor juristen en politicologen geldt ongeveer hetzelfde ${ }^{2}$. De uitzondering vormen de rechtshistorici, die veel te goed weten dat de scheidslijn in de rechtsontwikkeling van Nederland niet in 1813 ligt, of in 1848, maar in 1795-96 bij de vorming van de Bataafse Republiek ${ }^{3}$.

De totstandkoming van de staatkundige eenheid van ons land; de formulering en erkenning tegelijk van de rechten van de mens; de scheiding van kerk en staat en de typisch Nederlandse

\footnotetext{
${ }^{1}$ Bij wijze van voorbeelden: de instelling door de minister van BZK, mevr. dr. G. ter Horst, van een officieel comité ter herdenking van $1813-1815$, terwijl er nooit een comité ter herdenking van 1798 is geweest. Ik heb daarover geschreven: De viering van een orangistische staatsgreep en de bezetting van België, of: geschiedvervalsing dankzij een linkse minister, in: Jaarboek Vereniging van Griffiers, 6(2010), 60 - 62. Zie ook het overigens prachtige overzicht, dat eveneens in 1813 begint, van P. de Rooy, Republiek van rivaliteiten. Nederland sinds 1813, Amsterdam z.j. (2002); H.W. Blom e.a. (red.), Bicameralisme. Tweekamerstelsel vroeger en nu, 's Gravenhage 1992. Het boek laat ten onrechte het tweekamerstelsel in Nederland beginnen in 1815 in plaats van 1798.

${ }^{2}$ Voorbeelden uit de juridische literatuur: P.P.T. Bovend'Eert en H.R.B.M. Kummeling, Het Nederlandse Parlement, Deventer 2010 (11); Ernst Hirsch Ballin, De Koning. Continuïteit en perspectief van het Nederlandse koningschap, Den Haag 2012. Uit de politicologie: Rudy B. Andeweg and Galen Irwin, Governance and Politics of The Netherlands, Hampshire/New York 2002.

${ }^{3}$ Zie bij voorbeeld: O. Moorman van Kappen en E.C. Coppens (red.), De Staatsregeling voor het Bataafsche Volk van 1798. Opstellen opgedragen aan de nagedachtenis van dr. mr. L. de Gou, Nijmegen 2001; M.W. van Boven, De rechterlijke instellingen ter discussie. De geschiedenis van de wetgeving op de rechterlijke organisatie in de periode 1795 - 1811, Nijmegen 1990; A.M. Elias en P.C.M. Schölvinck, Volksrepresentanten en wetgevers. De politieke elite in de Bataafs-Franse tijd 1796 - 1810, m.m.v. H. Boels, Amsterdam 1991.
} 
vormgeving daarvan, het dateert allemaal van de eerste jaren van de Bataafse Republiek vanaf 1795. Dat geldt ook voor het eerste, weliswaar mislukte maar op lange termijn invloedrijke, experiment met de democratie in Nederland ${ }^{4}$.

\section{[2] Het Moment van Pieter Paulus.}

De eerste die daar, met blijvende intellectuele en politieke invloed, leiding aan heeft gegeven, was Pieter Paulus ${ }^{5}$. Hij was voorzitter van de commissie van vier die de Hollandse verklaring voor de 'regten en pligten van de mensch en de burger' in februari 1795 formuleerde en die in de andere gewesten van de voormalige Republiek vrijwel letterlijk is overgenomen. Hij leidde de beslissende onderhandelingen in mei 1795 met de Fransen over de Nederlandse onafhankelijkheid, nadat Franse troepen in januari 1795 de grote rivieren waren overgetrokken $^{6}$. Hij gaf ten slotte leiding aan de taaie onderhandelingen die leidden tot het 'Reglement ${ }^{7}$, dat het begin moest vormen van de nieuwe staat en de Nationale Vergadering in het leven riep, de eerste nationale volksvertegenwoordiging. Het eerste jaar van de 'Bataafse Vrijheid’ zoals het ambitieus heette, was het Moment van Pieter Paulus.

Paulus was afkomstig uit een Zeeuws-Vlaams regentengeslacht, in Axel geboren in 1753. In 1775 promoveerde hij in Leiden in de rechtsgeleerdheid, maar daarvoor had hij zich al onderscheiden met een eerste staatkundig geschrift over het stadhouderlijk regime (1773).

\footnotetext{
${ }^{4}$ Over het belangrijke historische onderzoeksproject 'The First Dutch Democracy. The Political World of the Batavian Republic, 1795 - 1801' onder leiding van de hoogleraren N.C.M. van Sas en W. Velema van de Universiteit van Amsterdam raadplege men: www.bataafse-republiek.nl.

${ }^{5}$ L. de Gou, Biografische bijdragen over achttiende-eeuwers. Fragmenten van jaarredes gehouden in de algemene vergadering van de Hollandsche Maatschappij van Wetenschappen 1979 - 1985, Haarlem z.j. (1985), 141 - 169; E.J. Vles, Pieter Paulus (1753 - 1796), patriot en staatsman, Amsterdam 2004; Arianne Baggerman en Rudolf Dekker, Ach stel U dien braven man tog ten voorbeelde. Pieter Paulus ( 1753 - 1796) in kleine kring, in: Nieuw Letterkundig Magazijn, 20 (2002/2), 34 - 43; Mart Rutjes, Door gelijkheid gegrepen. Democratie, burgerschap en staat in Nederland 1795 - 1801, Hilversum 2012 (verschijnt in oktober 2012).
}

\footnotetext{
${ }^{6}$ Vaak wordt de aanwezigheid van Franse troepen gebruikt als argument om van de Bataafse Republiek te spreken als van een 'satellietstaat' op zijn best en 'bezet gebied' op zijn slechtst. Ontegenzeglijk begon het op het eerste te lijken toen Napoleon, eenmaal keizer geworden, zich sterk met alle 'zusterrepublieken' ging bemoeien. Daarvan was in de eerste jaren na 1795 geen sprake. Het onderzoek van L. de Gou naar de totstandkoming van diverse staatsregelingen vanaf 1795 laat zien dat de staatsvorming in Nederland tot en met 1801 weinig hinder had van drukkende Franse bemoeienis. De Gou was dan ook beter gedocumenteerd dan H.T. Colenbrander, die eerder zeer veel had gedaan om de bronnen van deze periode toegankelijk te maken, maar die het b.v. moest stellen zonder de verslagen van de derde constitutiecommissie (voorjaar 1798), in tegenstelling tot De Gou. Wie de aanwezigheid van Franse troepen in Nederland als voldoende argument beschouwt om de Bataafse autonomie in twijfel te trekken, zou zich dienen te realiseren dat ons land vanaf 1787 werd bezet door Britse en Pruisische troepen, zonder welke stadhouder Willem V zich niet langer staande wist te houden. Burgers ontging het niet dat de Franse entree aanzienlijk geciviliseerder en gedisciplineerder verliep dan de Oranjefurie onder Pruisisch-Britse bescherming in 1787. Vgl. onder vele: Maarten W. van Boven (red.), Afscheid van de wereld. De autobiografie van Boudewijn Donker Curtius 1746 - 1832, Hilversum 2010. Anders: Remieg Aerts, Een staat in verbouwing. Van republiek naar constitutioneel koninkrijk 1780 - 1848, in Idem e.a., Land van kleine gebaren. Een politieke geschiedenis van Nederland 1780 - 1990, Nijmegen 1999, 38 - 47.
}

${ }^{7}$ G.W. Bannier, Grondwetten van Nederland, Zwolle 1936, 17 - 31. 
Daar was hij toen nog een voorstander van, zij het een kritische. Die kritiek nam tijdens de opkomst van de Patriotse beweging radicaler vormen aan, onder andere te lezen in een vierdelig boekwerk over de Unie van Utrecht (1775 - 1777), die destijds vaak werd beschouwd als een soort van grondwet. In dat boek manifesteerde Paulus zich als een staatsrechtgeleerde van het hoge niveau van Thorbecke later.

Grote bekendheid kreeg hij echter in 1793, in een tijd van repressie door de stadhouder, met zijn 'Verhandeling over de vrage: in welken zin kunnen de menschen gezegd worden gelyk te zyn? En welke zyn de regten en pligten die daaruit voortvloeien?' Daarin voerde hij een overtuigend pleidooi voor het beginsel van de rechtsgelijkheid en voor de rechten van de mens in het algemeen. Daarbij baseerde hij zich niet alleen op de bekende denkers van de Verlichting, maar allereerst op het Nieuwe Testament en de leer van Jezus ${ }^{8}$. Onder zijn vrienden en aanhangers leverde dit hem het predikaat 'de tweede apostel Paulus, die edele menschenvriend' op. Er moet wel worden bij verteld dat meer conservatieve denkers zijn verhandeling kenschetsten als 'het Fransche Jacobinismus in een christenkleedje'. Zijn opvattingen hebben in Nederland echter school gemaakt en ze zijn bepalend geweest voor onze verdraagzame constitutionele opvattingen over godsdienst en de scheiding van kerk en staat.

Intussen had Paulus ervaring opgebouwd als bestuurder bij de Rotterdamse Admiraliteit. Als Patriot was hij in 1787 door de Oranjerepressie uit zijn ambt gezet, maar daar was het bij gebleven. Hij vatte zijn advocatenpraktijk weer op en hoefde niet uit te wijken zoals veel van zijn vrienden. In januari 1795 staken de Franse troepen, als gezegd, de bevroren rivieren over en zij verjoegen de Engelse en Pruisische troepen, die tot dan toe het regime van stadhouder Willem V hadden moeten stutten. Op Paulus werd toen een beroep gedaan het gezag mede in handen te nemen: eerst in Rotterdam, vervolgens in de Hollandse Staten en ten slotte in de Staten-Generaal, waar de transformatie tot een nieuwe republiek vorm moest krijgen.

Ongeveer op de wijze waarop de advocaat Rutger Jan Schimmelpenninck in Amsterdam werd belast met het stedelijk gezag ${ }^{9}$.

Om te beginnen gaf hij leiding aan de fusie van alle admiraliteiten tot één ministerie van Marine, wat in oorlogstijd een essentiële opgave was. Voorts slaagde hij erin een hervormingsstrategie te doen accepteren in de Staten-Generaal die voorkwam dat de Bataafse Revolutie er een van wraak en geweld zou worden. Zo zou stap voor stap kunnen worden gewerkt aan de eenwording van het bestuur in Nederland. Uiteindelijk vond die haar vorm in het Reglement van eind 1795, een soort nood-grondwet die de toekomstige Nationale

\footnotetext{
${ }^{8}$ Ernestine van der Wall, Geen natie van atheïsten. Pieter Paulus (1753 - 1796) over godsdienst en mensenrechten, in: Jaarboek van de Maatschappij der Nederlandse Letterkunde 1996, 45 - 58; zie ook: S.R.E Klein, Patriots Republikanisme. Politieke cultuur in Nederland (1766 - 1787), Amsterdam 1995.

${ }^{9}$ L.J. Rogier, Rutger Jan Schimmelpenninck, 31 oktober 1761 te Deventer geboren, in: Idem, Terugblik en uitzicht. Verspreide opstellen van L.J. Rogier, Hilversum/Antwerpen 1965, 69 - 112; Theun de Vries, Rutger Jan Schimmelpenninck, Republikein zonder republiek, Nijmegen (SUN-reprint) 1979; L. Plemp van Duiveland, Schimmelpenninck 1761 - 1825. Levensloop en tijdsbeeld, Rotterdam 1971.
} 
Vergadering maar ook de provinciale besturen moest begeleiden in het proces van transformatie ${ }^{10}$.

Ik attendeerde al op Paulus' rol in de onderhandelingen met de Fransen over de toekomst van de Republiek, waarin de keuze was tussen de status van 'pays occupé' of een 'république soeur'. De Franse delegatie drong aanvankelijk sterk in de richting van een status als bezet gebied, maar moest mede op bevel van de eigen opdrachtgevers in Parijs maar ook dankzij de onverzettelijkheid van Paulus en de zijnen uiteindelijk meewerken aan de aanvaarding van de Bataafse Republiek als een zusterstaat. Tegen een hoge prijs, want de Fransen bleken redelijk hebberig (100 miljoen gulden vergoeding) en voor hun troepen gold de Republiek voortaan als bio-vakantieoord ${ }^{11}$.

In dit eerste, gevaarlijke en ingewikkelde jaar van de Bataafse revolutie toonde Paulus zich een staatsman als weinigen in de Nederlandse geschiedenis door zijn politieke moed, zijn buigzaamheid waar nodig, maar ook zijn intellectuele meesterschap. Niet toevallig sprak de Franse diplomaat Caillard over hem als: 'le célèbre Paulus, sans contredit la meilleur tête, l'homme le plus courageux et le plus éclairé de toute la République Hollandaise ${ }^{12}$. Het kon haast niet anders of juist hij werd gekozen tot eerste voorzitter van de Nationale Vergadering, die na veel geharrewar op 1 maart 1796 bijeenkwam in de voormalige balzaal van de stadhouder aan het Binnenhof, vanaf die dag tot 1991 de plaats waar de nationale volksvertegenwoordiging zou vergaderen. (En waar die natuurlijk had moeten blijven.)

Waarom zijn wij Pieter Paulus dan toch vergeten? De eerste reden is er een van persoonlijke tragiek. Aan het einde van die eerste samenkomst in Den Haag werd Paulus in optocht begeleid naar zijn woning in het huidige Ministerie van Defensie aan het Haagse Plein. Tijdens die optocht liep hij als goed revolutionair 'blootshoofds', dat wil zeggen zonder pruik over straat. Dat had hij in de snerpende koude van die $1^{\mathrm{e}}$ maart beter niet kunnen doen. Hij hield er een longontsteking aan over waaraan hij op 17 maart bezweek. Het Moment van Paulus duurde te kort. Dat was te meer het geval, omdat velen de overspannen verwachting hadden gekoesterd dat Paulus zijn bureaulade maar hoefde open te trekken en er zou een volledige schets van een grondwet uit tevoorschijn komen ${ }^{13}$. Toegegeven, zoals dat later bij Van Hogendorp in 1813 en bij Thorbecke in 1848 inderdaad het geval zou zijn. Paulus' bureaulade bleek echter leeg.

\footnotetext{
${ }^{10}$ Over het eerste jaar van de 'Bataafsche Vrijheid': P. Geyl, Geschiedenis van de Nederlandse stam (pocketeditie in zes delen), VI (1792 - 1798), Amsterdam/Antwerpen 1962; Rutjes, Door gelijkheid gegrepen.

${ }^{11}$ Aan de Fransen werden voorts Maastricht, Venlo en Staats Vlaanderen afgestaan, wat geen wonder was omdat vooral de vesting Maastricht steeds dienst had gedaan als bolwerk tegen mogelijke Franse aanvallen; dit vooruitgeschoven bolwerk leek vanaf 1795 zijn betekenis te hebben verloren. Mede daardoor zou Limburg later een andere positie innemen in het Nederlandse staatsverband dan Brabant, dat zijn oude ambitie volwaardig deel te zijn van de Republiek in 1795 zag gehonoreerd. P. Geyl, Nederlandse stam VI, 1564.

${ }^{12}$ De Gou, Biografische bijdragen, 163.

${ }^{13}$ De Gou, Biografische bijdragen, 168. Aldus berichtte een der Duitse gezanten, Bosset, aan zijn opdrachtgevers.
} 
Ontegenzeglijk was - de tweede reden - het eerste jaar van de Bataafse vrijheid ook een jaar van traagheid geworden. Aanvankelijk waren er snelle en effectieve beslissingen genomen, waarvan de fusie tot één Marine-ministerie er slechts een was. Vervolgens zakte de zaak weg in het moeras van de vertraging door de verlammende onderhandelingen over de onafhankelijkheid, die maanden lang in Parijs voortsleepten. Dat kwam enerzijds door interne onenigheid en hebberigheid bij de Fransen en anderzijds door het onvermogen van de Nederlandse delegatie onder Jacob Blaauw daar doorheen te breken.

Te laat werd daardoor werk gemaakt van het meer genoemde Reglement. Intussen was de sfeer van opgewektheid en vreedzaam vergelijk al verregaand verdwenen. Aan de ene kant kwamen radicale stromingen op die, zoals Isaac Gogel, een 'gerechtshof en een guillotine' hadden gewild in plaats van een halfslachtig Reglement ${ }^{14}$. Aan de andere kant waren er de provincies zoals Friesland en Zeeland, die aanvankelijk niets zagen in nationale eenheid noch in een Nationale Vergadering ${ }^{15}$. Die vermoedden toen al dat nationalisatie van openbaar bestuur ook nationalisatie van overheidsschuld met zich zou meebrengen. Arme regio’s zouden bij eenwording de gigantische staatsschuld van Holland mee moeten gaan dragen. Wie het huidige gekerm over de Griekse staatsschuld beluistert - en waar gaat die schuld in Europees perspectief nu helemaal over? - die kan zich de huiver voorstellen van de buitengewesten in de Bataafse Republiek.

Daar kwamen na de vroege dood van Paulus de dilemma's en de zeurende traagheid bij van het grondwettelijk wordingsproces. In de zomer van 1797 (weer meer dan een jaar later) leidde dit tot een 'Ontwerp van Constitutie', omineus 'het dikke boek' genoemd wegens zijn vele artikelen. Door de bevolking werd het in een referendum massaal met de grond gelijk gemaakt $^{16}$. Als U associaties krijgt met het referendum van 2005, dan klopt dat wel enigszins. 'Links' in de Nationale Vergadering raakte zijn geduld kwijt en de Franse broeders raakten evenzeer steeds meer geïrriteerd over dit gebrek aan politieke daadkracht. Dat leidde tot de kleine staatsgreep van 22 januari 1798, waarbij een aantal behoudende leden van de Nationale Vergadering 's ochtends bij entree op het Binnenhof eerst naar de kamer van de voorzitter werden afgevoerd en vervolgens gevangen gezet in paleis Huis ten Bosch. (Wat luxueuzer klinkt dan het was: het gebouw was al drie jaar buiten gebruik, het was een koude winter en het pand was onverwarmd.) ${ }^{17}$

\footnotetext{
${ }^{14}$ Geyl, Nederlandse stam VI, 1542 - 1543.

${ }^{15}$ Geyl, Nederlandse stam VI, 1567 - 1597; Tom Pfeil, 'Tot redding van het vaderland.' Het primaat van de Nederlandse overheidsfinanciën in de Bataafs-Franse tijd 1795 - 1810, Amsterdam 1998.

${ }^{16}$ Joris Oddens, Pioniers in schaduwbeeld. Het eerste parlement in Nederland (1796 - 1798), Hilversum 2012, hoofdstuk 7 (verschijnt na promotie auteur op 31 oktober 2012).

${ }^{17}$ Geyl, Nederlandse stam VI, 1725 - 1732; Oddens, Pioniers, h. 7. Over de toestand van de gevangen genomen parlementariërs: De Gou, Biografische bijdragen, 103 - 124 (Memorie J.B. Bicker over zijn detentie na 22 januari tot 12 augustus 1798). In zijn dissertatie beschrijft Rutjes (zie nt. 5) het verblijf in Huis ten Bosch als 'luxueus', maar dat kan het in het begin moeilijk zijn geweest.
} 
Daarna kwam het werk onmiskenbaar op stoom. De in het voorjaar gereed gekomen ontwerpStaatsregeling werd door de bevolking aanvaard in een referendum en aldus was er dan eindelijk gelegenheid de eerste Nederlandse democratie aan het werk te krijgen. Bij dat 'op stoom brengen' komen wij de tweede man tegen die ten onrechte is vergeten en die in feite het intellectuele werk van Paulus had overgenomen: ds. Willem Anthonie Ockerse. Zeker, een dominee; schrijven aan een grondwet is niet per se juristenwerk.

[3] De dominee en de Staatregeling van 1798.

Willem Anthony Ockerse ${ }^{18}$, in 1760 geboren in Vianen, had zijn theologie-opleiding gedaan in Utrecht en was gereformeerd (wij zouden zeggen: hervormd) predikant geworden in Baarn en in Wijk bij Duurstede. Dankzij een longziekte kon hij het predikambt niet goed uitoefenen, hoewel hij het tot 1797 volhield. Tegelijk was hij actief in een kring van geestverwanten in Amsterdam, die tot de radicale tak van de Patriotse beweging behoorden, en waar hij mannen ontmoette als Alexander Gogel, Samuel Wiselius, de remonstrantse theoloog Jan Konijnenburg en de publicist Wibo Fijnje. Gogel en Wiselius gaven samen in de jaren negentig het periodiek 'De Democraten' uit ${ }^{19}$. In dit gezelschap was de productieve publicist Ockerse in alle opzichten thuis. Onder zijn vele geschriften over allerlei onderwerpen viel er één de tijdgenoten al op: ‘Ontwerp tot een Algemeene Characterkunde’, een soort overzicht van de wijsgerige psychologie, in drie delen gepubliceerd tussen 1788 en 1797.

Van de eerste Nationale Vergadering was hij nog geen lid, maar dat werd hij wel van de tweede Vergadering die in september 1797 aantrad. Daar werd hij ook aanstonds opgenomen in de tweede constitutiecommissie van een en twintig leden, die vrijwel net zo verdeeld was als de eerste commissie, wat weinig goeds beloofde. Wel waren de radicale democraten - of, zoals zij ook wel worden genoemd: de Republikeinse Partij ${ }^{20}$ - daarin sterker geworden.

Ockerse behoorde spoedig tot degenen die genoeg kregen van het gebrek aan voortgang in het werk aan de grondwet en de weigering van buitengewesten bij te dragen aan de defensie. Zij zagen geen andere uitweg meer dan een greep naar de macht. Met Franse hulp, die vooral daarin bestond dat de Franse legers niet tegen de staatsgreep zouden optreden, kwam het op 22 januari tot 'de Omwending' zoals de tijdgenoten het noemden. Niet alleen werden behoudende parlementariërs gearresteerd en weigerden andere parlementariërs verdere medewerking, er werd ook een voorlopig Uitvoerend Bewind geïnstalleerd. Daarin hadden radicalen als Pieter Vreede (de leider van de coup) en de meer genoemde Wibo Fijnje het rijk voortaan alleen.

\footnotetext{
${ }^{18}$ Johanna Stouten, Willem Anthonie Ockerse (1760 - 1826). Leven en werk, Amsterdam 1982; N.C.F. van Sas, De ideoloog. Willem Anthonie Ockerse als exempel, in: Idem, De metamorfose van Nederland. Van oude orde naar moderniteit 1750 - 1900, Amsterdam 2004, 303 - 313.

${ }^{19}$ Van Sas, Metamorfose, 120 - 123; Herman de Lange, De politieke actie van een bewuste publieke opinie, in: De Gids, 134 (1971), 505 - 515.

${ }^{20}$ Over politieke partijen en/of stromingen: Joris Oddens, Pioniers (passim); Van Sas, Metamorfose, 277 - 291.
} 
De brede constitutiecommissie, waarin Ockerse al een grote rol had gespeeld, werd verkleind tot een commissie van zeven, nu onder zijn voorzitterschap ${ }^{21}$. Die zette er tempo in en dat kon ook, omdat er al heel wat gereed lag en het nu zaak was er enige coherentie en lijn in te brengen. Voorts echter moest rekening worden gehouden met de Franse ambassadeur die een Parijse regering vertegenwoordigde die nu wel eens resultaten wilde zien. Nederlanders moesten geen grondwetten schrijven; zij moesten mee oorlog voeren tegen de Engelsen. En oh ja, vooral zorgen voor het benodigde geld. Ambassadeur Delacroix, in december 1797 aangetreden, had een schets voor een grondwet uit Frankrijk meegebracht. Tussen Ockerse en de wel deskundige maar alleen Franstalige ambassadeur pendelde de uiterst onbetrouwbare secretaris Ducange. Die sprak wel Nederlands en was dikwijls bereid (zij het niet gratis, natuurlijk) zijn Franse chef om de tuin te leiden met berichten, dat de Nederlanders zich keurig hielden aan Delacroix’ adviezen; quod non.

In betrekkelijk korte tijd slaagde Ockerse erin de Fransen hun zin te geven waar dat onvermijdelijk was - een tweekamerstelsel bij voorbeeld ${ }^{22}$ - maar in hoofdzaak kwam er een geheel autochtoon product uit zijn handen, dat naar de eisen des tijds een aantal uitgesproken kwaliteiten had. Nadat het rompparlement, Constituerende Vergadering geheten, de tekst had goedgekeurd, werd zij opnieuw voorgelegd aan de bevolking. Het lichtelijk paranoïde uitgevallen interimbewind had nogal wat kiezers formeel uitgesloten van deelname aan het referendum, maar onderzoek heeft uitgewezen dat buiten de grote steden met de voorgeschreven uitsluiting de hand is gelicht ${ }^{23}$. De 'Staatsregeling voor het Bataafsche Volk' werd ook zonder dat geaccepteerd.

Dat hielp het interimbewind echter niet van zijn achterdocht af en het begon nu de ambtenarij te 'zuiveren,24. De onder het bewind functionerende 'agenten' (een ambt tussen ambtenaar en minister in) raakten daar zo door getergd, dat zij generaal Daendels - die de eerste staatsgreep

\footnotetext{
${ }^{21}$ Over de gang van zaken na 22 januari 1798: Rutjes, Door gelijkheid gegrepen; Simon Schama, Patriots and Liberators: Revolution in the Netherlands 1780 - 1813, New York 1977, 311 - 353.

${ }^{22}$ Het werd wel een bijzonder bicameralisme, waarbij de kiezers slechts één Wetgevend Orgaan kozen, maar zich dit nadien in twee Kamers opsplitste, waarbij de Eerste Kamer (de eigenlijke volksvertegenwoordiging met de meeste bevoegdheden) de Tweede koos. Het stelsel verdween bij ons in 1801, maar werd later geïntroduceerd in Noorwegen, waar het inmiddels, in oktober 2011, is opgeheven. Over het stelsel in de Bataafse Republiek: M.Rutjes, Door gelijkheid gedreven, hoofdstuk 4. De Eerste Kamer onder de Bataafse Staatsregeling, de eigenlijke volksvertegenwoordiging dus, bleef vergaderen in de zaal van de Nationale Vergadering, de oude balzaal van stadhouder Willem V. De Tweede Kamer van destijds (die wij nu Eerste Kamer noemen) vertrok naar de oude Statenzaal van Holland. Na 1848, toen de huidige Eerste Kamer in het openbaar ging vergaderen, keerde zij daarheen terug en bleef daar tot heden. Van 1815 tot 1848 huisde zij in de Treveszaal, waar nu de ministerraad vergadert.
}

${ }^{23}$ Jos. de Jong, 'Om door het volk te worden onderzogt en goed- of afgekeurd.' Een onderzoek naar de uitslagen van de referenda van 8 augustus 1797 en 23 april 1798, doctoraal-scriptie Universiteit Leiden (politicologie), 2007. De Jong bereidt een dissertatie over de beide referenda voor.

${ }^{24}$ Over de zuiveringen onder ambtenaren: Henk Boels, Binnenlandse Zaken. Ontstaan en ontwikkeling van een departement in de Bataafse tijd, 1795 - 1806, Den Haag 1993, 139 - 159; N.C.F. van Sas, Bataafse Terreur. De betekenis van 1798, Nijmegen 2011. 
militair had geleid - zo ver kregen opnieuw in te grijpen. Zo kon alsnog zorg worden gedragen voor volledige invoering van de nieuwe grondwet, algemene verkiezingen voor het nieuwe Wetgevend Orgaan en een ander Uitvoerend Bewind. Die tweede staatsgreep kwam er op 12 juni. Daarbij werden de gevangenen van 22 januari grotendeels bevrijd. Zij werden als het ware afgelost door de vijf afgezette Bewindvoerders, alsmede door parlementariërs als Ockerse. Nu kwam hij in Huis ten Bosch terecht als arrestant, maar in warmer weer. Ruim een maand later werd hij alweer vrijgelaten, maar hij had het met de politiek nu wel gehad. Hij begaf zich in zaken, wat geen succes werd; ging terug naar het predikambt, wat hem wel lag maar wat hij niet lang volhield. Langzaam verdween hij in de vergetelheid, al bleef hij wel schrijven en publiceren en gaf hij zelfs zijn memoires uit ${ }^{25}$. Zijn constitutionele meesterproef was, toen hij in 1826 overleed, echter al door vijf nieuwe grondwetsteksten ingehaald.

Ockerses Staatsregeling heeft gefunctioneerd tot 1801, twee jaar minder dan als minimum was bepaald. Dat lag ten dele aan een aantal eigenaardigheden van de constitutie, maar het lag ook aan het onvermogen van Uitvoerend Bewind en Agenten - kortweg, de regering - om met het parlement samen te werken. Omgekeerd manifesteerde het parlement met zijn twee kamers zich ook weer zo eigengereid en geneigd tot detailbemoeienis, dat het voor bewindslieden moeilijk werd in een redelijke tijd redelijke resultaten te behalen.

Agent Alexander Gogel mag dan een democraat zijn geweest, hij werd helemaal gek van de wijze waarop beide Kamers van het Wetgevend Orgaan met zijn voorstellen omgingen. Hij sprak in 1801 over het Wetgevend Orgaan in termen als: 'jaloersch van andere Machten, bemoeit (...) zich met alles, vit op alles en bedilt zonder kennis van zaken ${ }^{\text {,26 }}$. (Sommige kritiek op het parlement is, zo te horen, even oud als het parlement zelf.) Zijn knappe operatie om een nieuw en centraal geleid belastingsysteem van de grond te krijgen kostte hem drie volle jaren. In 1801 was de zaak rond; zij is tot 1821 niet tot uitvoering gekomen ${ }^{27}$. De agenten Gogel en Pijman (Agent van Oorlog) kregen er zo genoeg van dat zij het Uitvoerend Bewind tot verregaande hervormingsvoorstellen in de Staatsregeling dwongen. Toen de beide kamers van het parlement daar niet aan mee wilden werken, kwam het tot een derde staatsgreep, overigens tot groot ongenoegen van Gogel, die dit te ver vond gaan.

Het ging ook te ver. Hoewel de nieuwe Staatsregeling van 1801 minder slecht in elkaar zat dan later wel eens is betoogd, maakte zij grotendeels een einde aan de eerste Nederlandse democratie. Onbekendheid met de kenmerken van en werkwijze in een parlementair stelsel en onvermogen er adequaat mee te leren omgaan hadden de eerste democratie om zeep geholpen.

\footnotetext{
${ }^{25}$ W.A. Ockerse, Napoleontische redevoeringen, (twee delen), Amsterdam 1814 - 1815; H.W. Tydeman en J. Clarisse (red.), W.A. Ockerse. Vruchten en resultaten van een zestigjarig leven (drie delen), Amsterdam 1823 1826.

${ }^{26}$ De Gou (bew.), De Staatsregeling van 1801. Bronnen voor de totstandkoming, Den Haag 1995, 443 - 444.

${ }^{27}$ Pfeil, Redding van het Vaderland, 201 - 308.
} 
Overigens, ook internationale omstandigheden en de dreigende blik van de Franse Consul Napoleon Bonaparte droegen daaraan bij ${ }^{28}$.

Na een paar jaren grondwetsgeschiedenis werd al duidelijk dat het maken van een constitutie in vreedzame omstandigheden en zoekend naar consensus tot niets leidde of althans tot al te weinig. Er was zoiets als een politieke of maatschappelijke 'dreun' nodig - voldongen feiten kan men ze ook noemen - voordat onze constitutie in beweging bleek te brengen. Om het anders te zeggen: de Nederlandse politieke cultuur was toen al sterk in 'persuasie', in 'schikken en plooien', in 'het vertrouwde vaderlandse duw- en trekwerk' ${ }^{29}$. Zo goed, dat de eerste Bewindvoerders er niet tegen konden. Maar, ook koning Lodewijk Napoleon en nog later Willem I werden er horendol van. Toen het Nederlandse bestel echter moest scheppen en tegelijk kiezen, was het gedoemd te falen.

[4] Het 'wonder van 1848' en de macht van de voldongen feiten.

Als ik uitga van mijn eigen ervaringen in vijftig jaar waarneming van, onderzoek naar en deelname aan het politieke bedrijf in Nederland, dan kan ik die het best beschrijven als volgt. In en buiten de politiek wordt soms boeiend en ook wel eens heftig gediscussieerd over de noodzaak of wenselijkheid van staatkundige vernieuwing en bijbehorende veranderingen van de Grondwet. Maar, uiteindelijk komt het er niet van. Voorstanders van vernieuwing vormen al vanaf 1795 een minderheid en degenen die aarzelen kiezen na verloop van tijd meestal de zijde van de tegenstanders. Vraag is nu, of dit inderdaad als kenmerkend mag worden beschouwd voor onze grondwetsgeschiedenis ${ }^{30}$.

Natuurlijk, de parlementaire geschiedenis laat een aantal voorbeelden zien van systematische herziening van de Grondwet, zoals die van 1983 en eerder die van 1887 en 1922, om van de kleinere herzieningen niet te spreken. Maar, deze drie grote operaties hebben geen van alle tot belangrijke institutionele vernieuwingen geleid. Langs de gebruikelijke parlementaire wegen komen zulke vernieuwingen niet tot stand $^{31}$.

\footnotetext{
${ }^{28}$ Over de werking van het parlementaire stelsel tot 1805: J.Th.J. van den Berg en J.J. Vis, De eerste honderdvijftig jaar. Parlementaire geschiedenis van Nederland, 1796 -1946, Amsterdam 2012 (in productie).

${ }^{29}$ Termen als 'persuasie' en 'schikken en plooien' om de Nederlandse politiek in heden en verleden te kenschetsen zijn eerder gebruikt door de politicoloog H. Daalder. 'Het vaderlandse duw- en trekwerk', kenschets van hetzelfde fenomeen, is afkomstig van de historicus Joke Roelevink. H. Daalder, Van oude en nieuwe regenten. Politiek in Nederland, Amsterdam 1995, 149; J. Roelevink, 'Cette grande inertie qu'on rencontre sans cesse dans la marche des affaires. Lodewijk Napoleon als wetgever en uitvoerder, in: De Negentiende Eeuw. Documentatieblad Werkgroep 19e Eeuw, 30 (2006), 3 -4, 180.

${ }^{30}$ Het lijkt er sterk op dat de hier waargenomen historische scheidslijnen in het denken (en ageren) over constitutionele vernieuwing vanaf 1796 nauwkeurig samenvallen met Daudts veel latere tweedeling van de Nederlandse politieke stromingen in 'links' en 'niet-links', hoezeer men bij Daudts indeling geneigd is primair te denken aan sociaaleconomische tegenstellingen. H.Daudt, De ontwikkelingen van de politieke machtsverhoudingen in Nederland sinds 1945, in: Idem, Echte politicologie. Opstellen over politicologie, democratie en de Nederlandse politiek, Amsterdam 1995, 395 - 414.

${ }^{31}$ Ontegenzeglijk heeft dit ook zijn voordelen. Zo kwam bij de grondwetsherziening van 1938 niets terecht van een poging 'revolutionaire volksvertegenwoordigers' uit de Staten-Generaal te weren, een flagrante inbreuk op
} 
Des te intrigerender werd voor mij daarom de vraag waarom het in Nederland in het algemeen maar nooit wil lukken, maar in dat ene jaar, 1848 wel. Toen immers werd de Grondwetstekst van 1815 grondig en radicaal gewijzigd op basis van het rapport van een commissie onder voorzitterschap van Johan Rudolf Thorbecke, tot dan af en toe voor korte tijd Kamerlid geweest maar vooral bekend als de 'rode professor' uit Leiden. Die herziening bracht ons immers de rechtstreekse verkiezing van de Tweede Kamer, aanscherping en aanvulling van grondrechten, de nu vertrouwde parlementaire rechten van amendement, interpellatie en enquête en niet te vergeten de politieke ministeriële verantwoordelijkheid ${ }^{32}$.

Lag het aan de kwaliteit van Thorbeckes voorstellen? Dat willen wij natuurlijk graag geloven, maar dat is niet zo. Een vergelijkbaar voorstel uit 1844 was door de Kamer met de grond gelijk gemaakt, na zo’n typische uitstelmanoeuvre van vertragende procedures ${ }^{33}$. Dat, waar de Tweede Kamer zo goed in is als zij ergens geen zin in heeft maar het niet openlijk wil zeggen. Was het misschien de overtuigingskracht van de grote staatsrechtelijke denker die Thorbecke onmiskenbaar was? Ook dat helaas niet, want zijn hersens waren groot maar zijn karakter was een stuk kleiner: de Leidse hoogleraar was stug, inflexibel en rancuneus. Als hij zijn voorstellen zelf in de Tweede en Eerste Kamer had moeten verdedigen, was er waarschijnlijk niets van terecht gekomen ${ }^{34}$.

de parlementaire indemniteit. Zie: J.M.H. Dassen, De Grondwetsherziening 1938, Maastricht 1938. Zo komt er hopelijk evenmin iets terecht van de poging van het - nota bene - demissionaire kabinet-Rutte een wijziging van de Grondwet te bevorderen waarbij, om louter redenen van bezuiniging, het aantal leden van de Tweede en Eerste Kamer, evenals van gemeenteraden en provinciale staten-vergaderingen met een derde te verminderen. Een wetsvoorstel waar de zittende minister van BZK, mr. drs. L. Spies, voor haar aantreden nog van had beweerd tegen te zijn. Ook haar directe voorganger, mr. J.P.H. Donner, had er geen geheim van gemaakt niets in het wetsvoorstel te zien. Waarom dan toch dit in zijn onbenul antidemocratische voorstel bij de Tweede Kamer ingediend? Als er dan toch op de democratie moest worden bezuinigd, waarom dan niet alle volksvertegenwoordiging afschaffen? Dat is pas een besparing. Kamerstukken II, 2011 - 2012, 33345.

32 J.C. Boogman, Rondom 1848. De politieke ontwikkeling van Nederland 1840 - 1858, Bussum 1978; J.C. Voorduin, Geschiedenis en beginselen der Grondwet voor het Koningrijk der Nederlanden, volgens de beraadslaging deswege gehouden bij de beide kamers der Staten-Generaal, uit de oorspronkelijke stukken opgemaakt en aan den Koning opgedragen, Utrecht 1848. Zie voorts het 'journaal' van L.C. Luzac, lid van de Grondwetscommissie Thorbecke. Bijlage bij: B.H.D. Tellegen, 1848. Het voorspel van de herziening der Grondwet, in: De Gids, 47 (1883), 1 - 37; W. Thorbecke (uitg.), Dagverhaal van Thorbecke Maart 1848, in: De Gids, 67 (1903), 466 - 492. Over het 'wonder' van 1848: J.Th.J. van den Berg, Tweehonderd jaar grondwetgeving: historie en actualiteit (Daalderlezing 1998), in: Rechtsgeleerd Magazijn Themis, 159 (1998) 9, $299-307$.

${ }^{33}$ J. de Bosch Kemper, Geschiedenis van Nederland na 1830, met aanteekeningen en onuitgegeven stukken, deel IV, Amsterdam 1875, 452 - 569. Genoemde uitstelmanoeuvres deden niet af aan de soms hoge kwaliteit van discussie, niet alleen in 1844 maar ook en misschien nog wel meer in 1796 - 1798. Zie hiervoor onder andere de al genoemde dissertaties van M. Rutjes (nt. 4) en J. Oddens (nt. 16).

\footnotetext{
${ }^{34}$ Illustratief voor Thorbeckes rancuneuze trekken is zijn commentaar op de grondwetsvoorstellen van de regering in 1848 in zijn: Bijdrage tot herziening der Grondwet, 1848. Ook Boogman twijfelde in Rondom 1848 al sterk aan Thorbeckes vermogen zijn tegenstanders in de Hoge Colleges van Staat te overtuigen.
} 
Voor het politieke vakwerk bleek hij aangewezen op een andere progressieve liberaal, Dirk Donker Curtius, minder geniaal maar een vaardig politiek ambachtsman en iemand die, zoals Pieter Paulus, niet bang was uitgevallen. Toch zou ook dat waarschijnlijk niet voldoende zijn geweest, als daar niet de druk was geweest die koning Willem II op het vernieuwingsproces had gezet. Heel Europa was het slagveld van revoluties tegen de vorsten van de Restauratie en Willem II werd vanaf maart 1848 bezeten van de angst dat die revolutie ook hem de troon zou kosten. Nadat hij jaren lang elke poging tot hervorming, hoe bescheiden ook, had afgewezen, sloeg hem nu de schrik om het hart en als de dappere maar niet heel strategisch opererende militair die hij was, koos hij de vlucht naar voren en drukte de tegenstanders van de grondwetshervorming weg. Niet, omdat hij zo in die vernieuwing zelf geloofde, maar omdat hij die zag als politiek noodzakelijk voor zijn eigen overleven als vorst ${ }^{35}$.

Ministers en Staten-Generaal werden eenvoudig geconfronteerd met voldongen feiten. Wat Willem II deed, was in feite een machtsgreep à la 1798, zij het zonder geweld of arrestaties. Die bleken niet nodig. Thorbeckes voorstellen werden gebruikt als geschikt instrument om die machtsgreep te bestendigen. Willem II was, zoals hij zelf zei, 'in één nacht van uiterst conservatief uiterst liberaal geworden' en dat bleef hij totdat de nieuwe grondwet erdoor was. Kort daarna overleed hij, in maart 1849. Men moet Thorbecke nageven dat hij met het werk aan de herziening een hoog tempo aanhield. Dat hielp. Willem II's zoon, die aartsconservatief was gebleven, heeft zeker gestreefd naar terugdraaien van al die vernieuwing, met de blik gericht op Pruisen waar het ook allemaal was 'overgegaan'. Hij miste echter de competentie en het karakter om daarin te slagen; zijn aanhangers waren trouwens nog banger van hem en zijn grillen dan zijn liberale tegenstanders ${ }^{36}$.

Laat ons nog een stap verder terugzetten, naar eind 1813, toen de Franse troepen het land begonnen te verlaten en er een eind kwam aan de annexatie van ons land door het Franse keizerrijk van Napoleon. Hier kwamen de voldongen feiten van een Haags orangistisch driemanschap onder aanvoering van Gijsbert Karel van Hogendorp. De omstandigheden waren nog erg onzeker. In de zomer van 1813 hadden de burgers van Hamburg gedacht van de Fransen te zijn verlost en zij hadden hun eigen bestuur gevormd. Toen echter waren de bezetters onverwacht teruggekeerd en hadden zij gruwelijk huisgehouden onder bestuurders en burgers. De stedelijke elite in regeringscentrum Amsterdam zag in november wel, hoe de Franse bestuurders van stad en land het paleis op de Dam verlieten op weg naar het zuiden,

\footnotetext{
${ }^{35}$ Willem II's sympathie lag meer bij ambassadeur G. Schimmelpenninck (zoon van de gewezen raadpensionaris van 1805 - 1806), die niets zag in persoon en verrichtingen van Thorbecke. Schimmelpenninck wilde drastische wijzigingen aanbrengen in Thorbeckes voorstellen, die overigens buiten de premier om aanstonds na voltooiing waren gepubliceerd. Terugdraaien van deze voorstellen durfde de koning niet aan; Schimmelpenninck nam ontslag. Boogman, Rondom 1848, 50 - 84.

${ }^{36}$ Over Willem III: E. van Raalte, Staatshoofd en ministers. Nederlands Constitutionele Monarchie historischstaatsrechtelijk belicht, Zwolle 1971; Paul van 't Veer (red.), Maar Majesteit! Koning Willem III en zijn tijd. De geheime dagboeken van minister A.W.P. Weitzel, Amsterdam 1968.
} 
maar zij bleven met het oog op de Hamburgse gebeurtenissen maar liever heel voorzichtig en wachtten $\mathrm{af}^{37}$.

Zo niet Van Hogendorp en zijn companen. Zij namen het reële risico en riepen het herstel van de onafhankelijkheid uit. Van Hogendorp pretendeerde daarbij de oude Republiek van vóór 1795 in ere te zullen herstellen, maar hij zou vooral namen herstellen, maar tegelijk veel nieuws uit de Bataafse periode onder oude benaming overnemen. En anders wilde prins Willem dat wel, die op uitnodiging van Van Hogendorp vanuit Engeland, waar hij destijds verbleef, per boot terugkeerde naar Nederland. Ook hier een greep naar de macht en het scheppen van voldongen feiten, waaraan de Oranjevorst graag meewerkte, vooral toen Amsterdam en de nieuwe elite uit de Bataafs-Franse periode ondersteuning bood. Lodewijk had ons immers al aan het koningschap laten wennen; het was goed bevallen, ook als institutie van modernisering ${ }^{38}$.

In hoog tempo kwam in het voorjaar van 1814 een nieuwe Grondwet tot stand, die in gering democratisch en parlementair gehalte weinig afweek van de Constitutie van Lodewijk Napoleon. Nederland bleef een eenheidsstaat met een 'zelfbesturende' koning, ook al heette de Nationale Vergadering van destijds nu weer Staten-Generaal en ging Lodewijks Staatsraad weer Raad van State heten. Herstel van de democratie kwam er niet. Daar waren niet alleen de orangistische regenten tegen maar ook de bestuurders onder de beide Napoleons zoals C.F. van Maanen, die soepeltjes van het ene regime in het andere was gestapt ${ }^{39}$. Die bovendien redelijk sterk tegenwicht bood aan Van Hogendorp in de grondwetscommissie. De daaropvolgende annexatie van de zuidelijke Nederlanden, het latere België, in 1815 was het volgende voldongen feit voor alle betrokkenen, vooral natuurlijk voor de Belgen. Het zou leiden tot een nieuwe Grondwet, in twee talen, die een systematischer aanzien kreeg dan het eerdere werkstuk van Van Hogendorp maar zonder grote institutionele wijzigingen bleef. Wel hebben wij er de Eerste Kamer aan overgehouden ${ }^{40}$.

[5] Grondwetsherziening in geduldige consensusvorming.

Mijn betoog wekt tot nu toe sterk de indruk dat wij in Nederland, zonder grepen naar de macht en zonder voldongen feiten, niet bij machte zijn tot een enigszins behoorlijke herziening van de Grondwet of, als U wilt: tot een nieuwe Grondwet. Dat dreigt wel erg ver te gaan. Ten dele hangt het af van de ooghoek waarmee men kijkt. De stelling van de voldongen feiten gaat vooral op als het gaat om meer of minder sterke veranderingen in de politieke inrichting van de staat. Als de verwachtingen bescheidener zijn en het ook mag gaan om reële

\footnotetext{
${ }^{37}$ H.T. Colenbrander, Inlijving en Opstand, Amsterdam 1941, 173 - 318.

${ }^{38}$ De Negentiende Eeuw, 30 (2006) 3-4, Themanummer Het Koninkrijk Holland (1806 - 1810).

${ }^{39}$ Matthijs Lok, Windvanen. Napoleontische bestuurders in de Nederlandse en Franse Restauratie (18131820), Amsterdam 2009, 258 - 262.

${ }^{40}$ J. de Bosch Kemper, De staatkundige geschiedenis van Nederland tot 1830, Amsterdam 1868, 402 - 493; H.T. Colenbrander, Vestiging van het Koninkrijk (1813 - 1815), Amsterdam 1928, 48 - 92 en 156 - 213. Hogendorps restauratieve werkzaamheid, zo blijkt, concentreerde zich op het regionale bestuur en de rechterlijke macht.
} 
verbeteringen van zwakke teksten of versterking van bestaande instituties, dan zijn voldongen feiten minder vereist.

Een paar voorbeelden ter illustratie. In 1887 kwam een aanzienlijke verbetering tot stand van het binnenlands bestuur door de introductie van het 'medebewind' bij de decentrale overheden. Niet langer voerde een burgemeester rijkscommando’s uit, maar het gemeentebestuur werd in betrekkelijke autonomie betrokken in het nationale beleid ${ }^{41}$. In 1922 ontstond de mogelijkheid andere vormen van democratisch openbaar bestuur tot stand te brengen dan alleen gemeenten, provincies en waterschappen ${ }^{42}$. Het bestuur van de IJsselmeerpolders heeft er veel plezier van gehad. In 1938 kwam daar de publiekrechtelijke bedrijfsorganisatie bij ${ }^{43}$. Vanaf 1947, bij een kleine herziening, kennen wij de staatssecretaris $^{44}$, nadat in 1938 de minister zonder portefeuille ${ }^{45}$ was geïntroduceerd. Dan hebben wij het nog niet over de vele technische en juridische verbeteringen of moderniseringen die het gevolg waren van een ‘algehele herziening' van de Grondwet zoals in 1887, 1922 en 1983.

Laat ons, bij wijze van voorbeeld van zo’n grondwetsherziening in geduldige consensusvorming, wat nauwkeuriger kijken naar de herziening van 1887, de eerste na de grote liberale verandering van 1848. Die werd geleid door Jan Heemskerk Azn. ${ }^{46}$, een premier van liberale herkomst maar door de liberalen in de Tweede Kamer als een conservatief beschouwd. In een tijd van opkomende fracties in de Kamer was Heemskerk een 'politicus zonder partij'. Hij moest het dus niet van machtsgrepen hebben maar juist van buigzaamheid en tussen de klippen doorvaren. Het was dus maar goed dat hij niet de sterke opvattingen had van Thorbecke of Ockerse en Hogendorp eerder; hij was wel een scherpzinnig jurist.

Er moest iets gebeuren toen Heemskerk aantrad in 1883, voor de derde keer trouwens. Het kiesrecht was gebonden aan een aanslag in de directe belastingen, maar die koppeling maakte zowel modernisering van het kiesrecht als van de belastingen onmogelijk ${ }^{47}$. Terwijl beider modernisering bittere noodzaak was geworden. Daarnaast was er de strijd om het (lager) onderwijs. Christelijke politici wilden overheidssteun voor de bijzondere school. Liberalen wilden dat niet, omdat het ten koste zou gaan van het openbare onderwijs. Zij konden zich beroepen op de Grondwet, die immers bepaalde dat 'het openbare onderwijs voorwerp van

\footnotetext{
${ }^{41}$ J.Th. Buijs, De Grondwet, derde deel. Toelichting en kritiek van de wijzigingen in 1887 ingevoerd, Arnhem 1888, $250-255$.

${ }^{42}$ F.H. Huart, Grondwetsherziening 1917 en 1922, Arnhem 1925, 334 - 336.

${ }^{43}$ J.M.H. Dassen, De Grondwetsherziening 1938, Maastricht 1938.

${ }^{44}$ H.A. Groeneveld, De staatssecretaris in Nederland 1948 - 1988, Deventer 1989, 19 - 33.

45 J.W.M. Engels, De Minister zonder Portefeuille, Groningen 1987, 12 - 18.

46 J.J. Huizinga, J. Heemskerk Azn. (1818 - 1897). Conservatief zonder Partij, Harlingen 1973.

${ }^{47}$ Christianne Smit, Omwille der billijkheid. De strijd over de invoering van de inkomstenbelasting in Nederland, Amsterdam 2002, 193 - 235.
} 
aanhoudende zorg van de regering' was. Waarop de christelijke Kamerleden, onder aanvoering van de protestant A.F. de Savornin Lohman en de katholiek mgr. dr. H. Schaepman, zeiden dat zij aan geen enkele grondwetsherziening konden meewerken als er geen regeling voor het bijzonder onderwijs $\mathrm{kwam}^{48}$. Daarnaast was er de wenselijkheid van een systematische herziening van de Grondwet, waarvoor alle toenmalige hoogleraren in het staatsrecht in de grondwetscommissie waren gezet. Dat kon makkelijk, want het waren er nog maar drie ${ }^{49}$.

Wat was het effect van ontbrekende voldongen feiten maar wel een schrandere en ervaren minister-president? Er kwam een grondige en systematische herziening van de Grondwet ${ }^{50}$ de juristen hadden alle reden tot tevredenheid - maar op de politiek hete kwesties kwam het tot een compromis dat halve oplossingen leverde. Het kiesrecht werd geregeld met een tekst van elastiek - men noemde het destijds: een 'caoutchouc-artikel'- die aanleiding zou geven tot giftige politieke conflicten in de jaren erna, vooral tussen liberalen onderling. De onderwijskwestie kon alleen maar worden bijgelegd, doordat de Eerste Kamer concludeerde dat de bestaande Grondwetstekst helemaal niet in de weg stond aan subsidie van bijzondere scholen. De Grondwet kon niet alleen gelezen maar ook geïnterpreteerd worden.

Dit alles, na vijf jaar onvermoeibaar maar ook vruchteloos parlementair debat. Het record van 1798 was ruimschoots gebroken. Er was een nieuwe gedeeltelijke herziening van de Grondwet in 1917 voor nodig om op deze twee politieke hoofdzaken de verhoudingen tot 'bevrediging' te brengen. Let wel: dertig jaar na dato. Dit gebeurde door de financiële gelijkstelling van openbaar en bijzonder onderwijs en door de totstandkoming van het algemene kiesrecht ${ }^{51}$. (De gewone wet moest maar bepalen wanneer dat ook voor vrouwen zou gaan gelden.) Dit laatste bevestigt de indruk dat met vreedzaam overleg alleen vernieuwing ofwel niet tot stand komt, ofwel halfslachtig, ofwel erg laat. Want Nederland was er niet echt vroeg bij met het algemene kiesrecht. Ook latere voorbeelden werken bevestigend: in 1922 kwam uiteindelijk het referendum er niet door, noch de afschaffing van de Eerste Kamer; in 1983 kwam het niet tot een rechtstreeks gekozen minister-president. ${ }^{52}$

\footnotetext{
${ }^{48}$ W.J. van Welderen baron Rengers, Schets eener parlementaire geschiedenis van Nederland van 1849 tot 1891 , tweede deel, 's Gravenhage 1906 (tweede gewijzigde druk), 303 - 394.

${ }^{49}$ Buijs (Leiden), De Geer (Utrecht), Tellegen (Groningen). Van Welderen Rengers, Schets II, 306.

${ }^{50}$ Zie in het bijzonder de grondige analyse door Buijs van de herziening van 1887 in zijn: Grondwet III.

${ }^{51}$ C.W. de Vries, Schets eener parlementaire geschiedenis van Nederland, vierde deel, Nederland 1914 - 1918 , 142 - 186; Jasper Loots, Voor het volk, van het volk. Van districtenstelsel naar evenredige vertegenwoordiging, Amsterdam 2004, 123 - 144. Dat niet elke liberaal gelukkig was met de onderwijspacificatie wordt aangetoond door P.G.C. van Schie, Vrijheidsstreven in verdrukking. Liberale partijpolitiek in Nederland 1901 - 1940, Amsterdam 2005, 179 - 189.

${ }^{52}$ P.J. Oud, Het jongste verleden. Parlementaire geschiedenis van Nederland, deel I, 1918 - 1922. Assen 1968 (2), 324 - 391. Over de betekenis van de motie van het Tweede Kamerlid van der Sanden (KVP), gericht tegen de rechtstreeks gekozen minister-president in 1974: J.Th.J. van den Berg, Democratische hervormingen, politieke machtsverhoudingen en coalitievorming in Nederland, in: Acta Politica, 21 (1986), 273.
} 
Toch, soms komen vernieuwingen tot stand die er op moment van aanvaarding uitzien als van gering belang, maar die na verloop van soms vele jaren blijken een fundamenteel vernieuwend effect te hebben gehad. Dat, wat ik eerder al eens het verschijnsel heb genoemd van de ‘kleine muisjes met lange staarten' van onze Grondwetsgeschiedenis ${ }^{53}$. Voorbeeld daarvan is het onbeperkt voorrang geven in onze Grondwet aan regels van internationaal recht boven eigen nationaal recht (in artt. 91 - 93 Grw., sinds 1953). Daarmee zijn wij niet alleen de Europese Unie binnengegaan en onderdeel geworden van een volledig nieuw en bovennationaal constitutioneel bestel. Ironie: toen de Nederlandse bevolking er in 2005 tegenstemde, was dat bestel er op hoofdzaken al geruime tijd. Maar ook is aan de rechter op die manier een bevoegdheid tot constitutionele toetsing verschaft, die het grondwettelijk verbod daarop loos heeft gemaakt. Het laatste werd door vrijwel niemand voorzien; het eerste is onmiskenbaar wel voorzien, maar niet in de draagwijdte die het inmiddels heeft aangenomen.

[6] Slot: 'framing' in de constitutionele geschiedschrijving.

Wanneer is onze grondwetsgeschiedenis nu eigenlijk begonnen? Om die vraag te beantwoorden moet ik eerst een andere kwestie aan U voorleggen. De vraag namelijk: wanneer is er sprake van een 'nieuwe grondwet' en wanneer spreken wij van een 'grondwetsherziening'? Van 1798 tot en met 1814 is er steeds gesproken van een nieuwe grondwet, al volgden de nieuwe teksten kort op elkaar, zoals in 1801, 1805, 1806, en 1814. Vanaf 1814 hebben wij het aldoor gehad over herziening van de Grondwet, alsof het steeds om wijzigingen ging met behoud van structuur en grote delen van de bestaande tekst. Zo eenvoudig is het echter niet. De tekst van 1848 wijkt op een reeks essentiële punten af van die van 1814 en 1815, meer dan de laatste twee van de Constitutie van 1806. De huidige Grondwet, van 1983, lijkt niet op die van 1814 en niettemin doen wij of de huidige tekst op die van 1814 is gebaseerd ${ }^{54}$. De keuze van de term 'nieuw' of 'herziening' zit dus niet in de tekst zelf, noch in de mate waarin nieuwe versies van vorige afwijken.

Blijkbaar hebben wij het over een politiek bepaalde terminologie, waarbij in het ene geval moet worden benadrukt dat het om iets geheel nieuws gaat en in het andere geval het van doorslaggevend belang wordt gevonden om de continuïteit te benadrukken. Historisch gesproken is er veel te zeggen voor de stelling dat alle grondwetgeving van twee eeuwen telkens herziening is geweest van de eerste en oorspronkelijke tekst van de Staatsregeling van 1798. Dan wordt en passant duidelijk dat grondwetgeving geen geschiedenis is van rechtlijnige vooruitgang en democratisering maar eerder van achteruitgang vanaf 1801 en later, totdat er vanaf 1848 weer aan democratisering werd gewerkt. Als het om het referendum en om het kiesrecht voor alle ingezetenen gaat, lopen wij trouwens nog steeds achter bij de

\footnotetext{
${ }^{53}$ J.Th.J. van den Berg, De grote lijn in de Nederlandse politiek van de twintigste eeuw, in: Corrie van Eijl e.a. (red.), Sociaal Nederland. Contouren van de twintigste eeuw, Amsterdam 2001, 43 - 44.

${ }^{54}$ Raadpleeg voor tekstvergelijking: www.denederlandsegrondwet.nl. Meer over deze kwestie in: Van den Berg en Vis, De eerste honderdvijftig jaar, (in productie).
} 
grondwet van 1798. Men mag het ook omkeren, wat mij betreft, en in een aantal gevallen, ook na 1814, spreken van een 'nieuwe Grondwet', zoals in 1848, 1887, 1922 en 1983.

De gedachte komt sterk op, dat er een politiek oogmerk is geweest om het begin van onze grondwetsgeschiedenis vast te leggen bij 1814 en al het verrichte daarvoor te beschouwen als verwaarloosbare en mislukte probeersels. Zo kan gemakkelijker dan anders het noodgedwongen besef worden ontlopen dat de geschiedenis niet alleen vooruitgang laat zien. Bovendien is er reden voor het vermoeden van een sterk staaltje 'framing', dat wij hebben te danken aan Gijsbert Karel van Hogendorp en zijn vrienden. Zij waren het die grondwetgeving in Nederland historisch hebben weten te verbinden met de aanwezigheid en deelname van het Huis van Oranje, daarmee de suggestie wekkend -met veel historisch succes - dat Grondwet en koningschap een creatie zijn geweest van koning Willem I, prins van Oranje-Nassau. Dat de Grondwet bestaat sinds 1798 en het koningschap sedert 1806 wordt daarmee, opnieuw succesvol, genegeerd. Het is een interessante ironie van de vaderlandse geschiedenis dat men al lang geen orangist meer hoeft te zijn om in die fictie te geloven. Men hoeft ook helemaal geen 'Oranjehater' te zijn om dat met een zekere verwondering aan te zien $^{55}$.

Het is ook allemaal niet echt 'erg'. Het enige wat jammer is: zo vergeten wij een paar belangrijke staatslieden, waarvan wij er ook weer niet zoveel hebben dat wij hen zouden kunnen vergeten. Pieter Paulus hoeft geen 'edel menschenvriend', laat staan 'apostel' te zijn geweest om toch tot een van onze belangrijkste staatslieden te worden gerekend. Wij zouden die erkenning gestalte kunnen geven door wat nu op het Binnenhof de 'Oude Zaal' heet en die bijna tweehonderd jaar de vergaderzaal van de Tweede Kamer is geweest de naam te geven: Pieter Pauluszaal.

\section{Mijnheer de Rector Magnificus; Dames en Heren,}

In 2003 kwamen vier heren van de Capaciteitsgroep Publiekrecht van deze universiteit aan een aangename lunchtafel, hier dichtbij, met het verzoek om als hoogleraar voor één dag in de week studenten te onderhouden over het parlementaire stelsel. Dat waren Ad Geers, AaltWillem Heringa, Frits Stroink en Luc Verhey. Als je tegenover zo'n kwartet mensen wordt geplaatst, is geen nee meer mogelijk.

Ad Geers is inmiddels helaas niet meer onder ons en ik mis hem nog steeds. Graag erken ik dat Saskia Klosse, die zijn plaats heeft ingenomen, heel veel aan vriendschap en collegialiteit heeft goed gemaakt. Frits Stroink is intussen als hoogleraar vertrokken; aan de noodzakelijke opbouw van een nieuw privébestaan heeft hij terecht de voorkeur gegeven. De komst van Chris Backes heeft ook in dit geval veel goed gemaakt. Aalt-Willem Heringa heeft alle jaren

\footnotetext{
${ }^{55}$ Framing van de grondwetsgeschiedenis zal zonder twijfel geen exclusief Nederlands verschijnsel zijn. Vergelijkend onderzoek ernaar - zoals in het algemeen nagestreefd door het Montesquieu Instituut in Maastricht - zou interessante inzichten kunnen bieden en ongetwijfeld laten zien hoezeer de bouw en verbouw van constituties politieke activiteiten zijn.
} 
van mijn verblijf in Maastricht mij en anderen moeten besturen. Dat is nog geen aanslag op de collegialiteit, maar het heeft hem en mij onvermijdelijk op afstand van elkaar gehouden; groter afstand dan althans mij lief was. Gert-Jan Veerman was geen deel van het kwartet. Wij hebben elkaar iets later leren kennen tot mijn vreugde, onder andere in ons beider rol als Stadler en Waldorf tijdens voorheen de jaarlijkse 'Vaesharteltdagen'.

Luc Verhey was de enige die ik niet of nauwelijks kende in 2003. Ik heb nooit kunnen vermoeden dat hij mij op mijn oude dag nog het geschenk van een nieuwe en hechte vriendschap zou gunnen. Toch is het precies dat wat er is gebeurd en waarvoor ik hem buitengewoon dankbaar ben. Het is ook een productieve vriendschap geworden, in het bijzonder voor de opbouw van het Montesquieu Instituut, dat dus van mij Pieter Paulus Instituut had mogen heten. Dankzij dat instituut heb ik een aantal buitengewoon getalenteerde jonge onderzoekers en docenten leren kennen, met wie het aangenaam converseren was tijdens de lunch in een van de belendende eetcafé's - maar van wie ik ook veel heb geleerd. Dank ook aan de collegae van Europees recht en European Studies, die veel hebben bijgedragen aan de ontwikkeling van het Montesquieu Instituut. Dank ten slotte aan het College van Bestuur, in het bijzonder zijn oud-voorzitter Jo Ritzen. Het begon een beetje ingewikkeld -dat is bij Jo wel vaker zo - maar daarna hebben wij elkaar effectief kunnen ondersteunen; onze vriendschap is er slechts door gegroeid.

Mijn studie van de parlementaire geschiedenis stopt vandaag niet. Bij die studie zal ik wel een oude vriend, Jan Vis, erg missen, met wie ik samen het overzicht van onze parlementaire geschiedenis sedert 1795 zou beschrijven. Dat werk nadert gelukkig zijn voltooiing. Maar, hoe graag zou ik de perikelen van de huidige kabinetsformatie met hem hebben besproken, zoals wij tot en met 2010 hebben gedaan.

Tot mijn bijzondere vreugde is mijn leermeester, promotor en langjarige vriend Hans Daalder er vandaag wel, nog wel hierheen gereisd met een speciaal retourtje Florence-Maastricht. Veel dank voor je komst, Hans en trouwens ook veel dank aan degenen die je hebben geholpen hier vandaag te zijn, in vol ornaat.

Mijn belangstelling voor het werk van de collega's verdwijnt niet. Daarbij noem ik in het bijzonder het werk en de vriendschap van Carla van Baalen en haar staf van het Centrum voor Parlementaire Geschiedenis. Ik vermeld ten slotte graag het werk van het aanstormend talent in Nijmegen maar ook in Amsterdam, waar het Nederlands eerste democratie zo grondig en geëngageerd onderzoekt.

Voor de parlementaire democratie mag er soms reden zijn tot zorg; voor de parlementaire geschiedenis is er alle reden tot hoge verwachtingen.

Ik heb gezegd. 